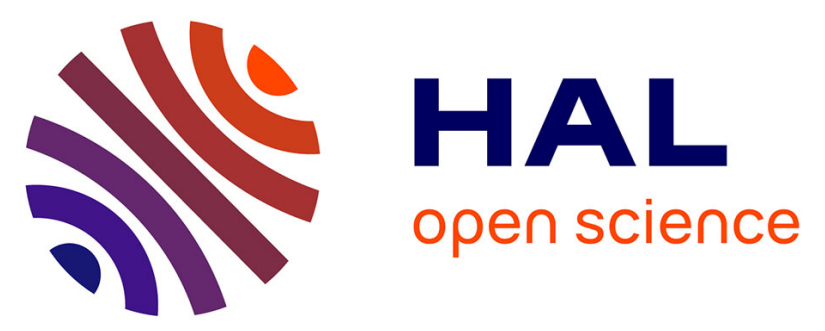

\title{
Surveillance, Radicalization, and Prison Change Self-Analysis of an Ethnographic Survey Under Tension
}

Gilles Chantraine, David Scheer

\section{To cite this version:}

Gilles Chantraine, David Scheer. Surveillance, Radicalization, and Prison Change Self-Analysis of an Ethnographic Survey Under Tension. Journal of Contemporary Ethnography, 2021, Journal of Contemporary Ethnography, pp.089124162110194. 10.1177/08912416211019454 . hal-03357909

\section{HAL Id: hal-03357909 \\ https://hal.univ-lille.fr/hal-03357909}

Submitted on 29 Sep 2021

HAL is a multi-disciplinary open access archive for the deposit and dissemination of scientific research documents, whether they are published or not. The documents may come from teaching and research institutions in France or abroad, or from public or private research centers.
L'archive ouverte pluridisciplinaire HAL, est destinée au dépôt et à la diffusion de documents scientifiques de niveau recherche, publiés ou non, émanant des établissements d'enseignement et de recherche français ou étrangers, des laboratoires publics ou privés. 
Surveillance,

Radicalization, and Prison Change Self-Analysis of an Ethnographic Survey Under Tension
Journal of Contemporary Ethnography

(C) The Author(s) 2021

Article reuse guidelines: sagepub.com/journals-permissions DOI: 10.1 |77/089|24I621।019454 journals.sagepub.com/home/jce

(9)AGE

\title{
Gilles Chantraine' (D) and David Scheer'
}

\begin{abstract}
This article is based on a sociological research, combining qualitative interviews and ethnographic observations, undertaken in "radicalization assessment units" in French prisons. We will first summarize the context of negotiating the research agreement, amidst a climate of panic on the part of political authorities who feared terrorist attacks. Then we will describe empirically the way the researchers were particular objects of surveillance on the prison grounds, in a way that was different, in its nature and unusual intensity, than the usual surveillance of other people who come into the prison. Lastly, we will show that this surveillance spreads beyond the prison walls, for example, the researchers were tailed when they left the prison. A reflexive work would explore all the ambiguities of this surveillance-from protection to control-and at the same time consider this surveillance of the researchers not as a contextual element of the study, but an object of the analysis in its own right. In doing so, this case study more broadly examines the methodological challenges of ethnography undertaken in
\end{abstract}

\section{'CLERSÉ — CNRS / Université de Lille, Cité scientifique Villeneuve d'Ascq, France}

\section{Corresponding Authors:}

Gilles Chantraine, CLERSÉ - CNRS / Université de Lille, Cité scientifique, Villeneuve d'Ascq, 59655, France.

Email: gilles.chantraine@univ-lille.fr

David Scheer, CLERSÉ — CNRS / Université de Lille, Cité scientifique, Villeneuve d'Ascq, 59000, France.

Email: david.scheer@univ-lille.fr 
difficult fieldwork together with a grounded theory capable of integrating into the analysis the vicissitudes and uncertainties of the research process itself.

\section{Keywords}

prison intelligence, surveillance, reflexivity, ethnography, radicalization, institutional change

\section{Introduction}

This article is based on a sociological research undertaken in 2017 and 2018 in "radicalization assessment units" (RAUs) in French prisons (Chantraine and Scheer 2020; Scheer and Chantraine Forthcoming). The RAUs are highsecurity units in which prisoners identified as "radicalized" 1 are transferred and assigned, generally on the basis of the criminal charge (offense of a terrorist nature) or suspected radicalization. ${ }^{2}$ Inside these units, the prisoners are evaluated over a 4-month period, in the attempt to gather objective signs of their degree of radicalization and potential to be dangerous. This assessment is conducted jointly by the prison officers who observe the prisoners daily and by psychologists, specialized educators, and probation officers who regularly meet with the prisoners. The aim of the assessment is to determine the nature of their detention and assignment at the end of this period. Depending on the results and recommendations at the end of the assessment, the prisoners, after their stay in the RAU, may be assigned to "ordinary detention" in a maximum-security prison, placed in solitary confinement, or else sent to a "radicalization management unit" (RMU). Although, only a minority of the prisoners considered as "radicalized" are assigned, temporarily, to the RAU, they are the cornerstone of the apparatus for the management and fight against radicalization in French prisons (Chantraine and Scheer 2020).

This study, with its focus not on individual paths of radicalization, but on the daily life in these units, falls in line with sociology's ethnographic tradition of "total" institutions (Goffman 1990) and more specifically the prison (e.g., Clemmer 1958; Sykes 1958; Bosworth 1999; Chantraine 2004; Liebling and Arnold 2004; Crewe 2009; Fassin 2015). The ethnographic approach is primordial for an intimate understanding of the prison world and for an analysis "starting from the bottom" of certain dynamics of institutional transformation. For this study, we are convinced of the analytical added value of a monographic approach ("analyzing "the whole" in the words of Liebling 2001) that situates and correlates the viewpoints of the different actors 
involved, rather than limiting itself to an analysis of just one "side" (prisoners, prison officers, and officials). It is based on a 100-day ethnographic observation during immersions in three French prisons and on over 90 semidirective or non-directive interviews, conducted both in the prison-with professionals and prisoners - and on the outside, with management and directors of the central and inter-regional prison administrations. Other interviews also took place in less formal — and more discreet — places. In addition to this set of observations and interviews, there is also the analysis of internal notes and "assessment reports" as well as that of political discussions and social controversies in the area, along with a vast set of grey literature. The sum of data gathered underpinned the project for a global analysis of the RAU apparatus involving sociology of institutions, professions, and work, as well as a sociology of individual experiences, adaptations, and resistance to incarceration.

The objective of this article is not a summary of the study's overall results, but rather an account of a particular facet of the study's conditions and dynamics, namely, the institutional surveillance - and the sensation of an omnipresent surveillance - experienced by the team throughout the research. This surveillance, which is contextualized and detailed empirically, shaped not only the ways data was gathered and the forms of protection against all types of intrusions, but also the researchers' subjective experience, ranging from uneasiness to excitement, a state of resignation, worry, and paranoia. A particularly apt expression for this is "panoptic personality" (Lyons 2004), denoting the subjective experience whereby the researchers have the impression that they may be the objects of surveillance that goes beyond the context of the fieldwork itself and potentially affects all facets of their daily lives. In turn, and gradually, this surveillance was integrated into the very object of the analysis in the context of a renewed research strategy (Boumaza and Campana 2007).

Our account is organized into three steps. In the first part, we will discuss the context of the research agreement negotiations between the Prison Administration Directorate (DAP) and the National Centre for Scientific Research (CNRS). This context was marked by the climate of panic among political authorities due to the fear of further terrorist attacks and the obligation of these same authorities to demonstrate their ability to take action and manage the crisis. This had a domino effect, for the climate was also marked by an increased pressure on the prison administration to "understand quickly so as to act quickly," since the prison was regularly suspected of being a "school" or a "fertile ground" for radicalization. In the second part, we will describe how, in the prison, the researchers were the object of special surveillance; we also discuss the protective, occasionally paranoid, reactions that can provoke. Being under surveillance and monitoring in prison is a 
commonplace experience. However, what is of particular interest to us are the new modalities for this surveillance and the new actors carrying it out. Lastly, in the third part, we will show that the experience of surveillance is not spatially bound by prison walls - as is often the case for studies undertaken in prisons - and we will attempt to interpret the consequences of this surveillance "beyond the walls."

These sections, organized by the study sites ("general direction," "prison," and "outside" the prison) lay out a reflexive work that transversally explores the three theoretical and practical issues at stake, which will be described throughout the demonstration. The first issue relates to the deep-seated ambiguities of institutional surveillance, ranging from concerns to protect the researchers, to the prison administration professionals' resistance to the potential disturbance the former cause in the prison and on to the attempts by certain actors to obtain access to their data, considered to be highly sensitive. The second issue that shapes the account of the different places and steps of the research relates to the experience of any researcher working in a prison environment, but in this case with an unusual intensity given the highly sensitive nature of anti-terrorism. This experience is one of negotiating at several levels: the researchers do not negotiate solely with an "institution" but also with different actors (the research unit, the prison director, the prison officers, etc.) who each may develop distinct interests or misgivings about the research. Lastly, the third issue is the way that, despite all efforts to maintain independence and neutrality, the researcher is taken up in asymmetrical power relations between the prison officers and the prisoners, and as such, reproduces them partially, despite all their efforts to minimize them. The asymmetry of the relations negotiated with the professionals and the prison officers can give rise to "edifying qualms" (Martin 2019), which are just as much moral dilemma as they are precious sources of information.

The account presented — and its illustration by cross-referencing field journals - is written in the first person, either singular ("I") or plural ("we"). This narrative dialectics enables us to convey the tension between individualized surveillance of one or another researcher at different times of the study - through wiretapping, being tailed, contacts by the intelligence services - and a broader surveillance of the dynamics of the whole team and their study, from persistent institutional requests on progress made in the study to injunctions to modify the final research report and remove certain data deemed to be "too sensitive."

\section{From the Negotiation to the First Warning}

From 2015 to 2017, the political context regarding terrorism and counterterrorism was extremely tense. In addition to a rapid succession of three Prime 
Ministers and four Ministers of Justice, we can also cite French military intervention in Mali, Iraq, and Syria against the threat of Islamists; counterterrorism plans that followed one after another; resignation of the director of the prison administration, introduction - and later extension - of the state of emergency; increased powers assigned to the intelligence services in the fight against terrorism (in particular, see Hamilton 2019). Various measures against terrorism or to bolster homeland security were adopted: massive military deployment in public space; protection of so-called "sensitive" sites (houses of worship, schools, and train stations); extension of intelligence agency powers; harsher prison sentences for public outrage, rebellion or threat; installation of sections to fight violent radicalization in several administrations, and so on.

The prison administration did not elude this groundswell and its services were reorganized to take this terrorist threat into account: a "security" subdirectorate created in the central administration, installation, and reinforcement of a service dedicated to the Mission to Fight against Violent Radicalization (MLRV), development of intelligence through the Central Office for Penitentiary Intelligence (BCRP, later becoming the National Service for Penitentiary Intelligence), and so on. From 2015, prison security became a key priority for the Justice Minister, who called for extending investigation and control measures inside prisons, reinforcing the means of the police, and developing a penitentiary intelligence of its own. The prison administration was under intense pressure regarding its capability to deal with the new threats to homeland security and its duty of vigilance toward risks of intra-muros proselytizing and radicalization.

In this general context, the institutional measures taken for reception and assessment of people incarcerated for terrorist acts or identified as "radicalized" are the fruit of a short, but intense, history. Different specialized units quickly appeared, one after the other: "Proselytism Prevention Unit" (2014), "Dedicated Unit" (January 2016), "Radicalization Prevention Unit" (RPU, June 2016), "Radicalization Assessment Unit" (October 2016), or even the "Radicalization Management Unit," which replaces the "Violent Inmate Unit." Each time the political authorities were faced with a key question: should this prison population be grouped together in specific units, or else spread out in normal prisons? And in each of these options, how, using which methods and with which objectives? Faced with these questions and the need to analyze the special units set up, the prison administration, through its "statistics and study office" "3 began its search for a team that could carry out research on how "radicalized" prisoners were dealt with in the specific units. Negotiations with the prison administration management began in September 2016, shortly before the RPUs were closed. 


\section{A Warning}

Several weeks after being contacted by the prison administration's "research office" I'm invited to a first meeting, along with a research engineer who's to join the team and a member of the CNRS "partnership" service. At the prison administration offices, we are received by the head of the DAP's "CounterTerrorist Plan" (PLAT), and by three members of the "research office". These different professionals are all aware of my earlier studies have asked for me specifically because of this background and knowledge. The Minister of Justice would like a quick evaluation on the way the RPU operate. It's a serious subject: the number of "terrorists" in prison is constantly rising, and there's a real risk of a new attack: "something must be done". It's a "vital" question but with a limited budget and a very tight schedule. . . Furthermore, during this negotiation we are warned that "the political pressure will be enormous". At the end of the meeting the head of PLAT exclaims: "I warn you, there will be eyes on you!"

The very notion of surveillance, even more so in a prison environment, incorporates the issues of both protection (the prison administration is responsible for the researchers' safety) and control (limiting disturbances to the institution occasioned by the researchers' presence). We also understand that the sensitive nature of our data is of particular interest to a whole series of institutional actors: if it was a question of their "eyes on us," they were also eyeing our data. We hesitated: should we take it on or not? During the internal hesitations between the future research director and his team in germination, we evoked the risk of political pressure and the fear of an a posteriori instrumentalization. Several services were mobilized during a discussion that lasted 6 months: the National Commission for Informatics and Liberty (CNIL), the CNRS "legal services," various DAP services, and so on. During the negotiation, we managed to convince our interlocutors to transform the initial order from a rapid research project — with a normative and operational scope - toward a longer-lasting research, independent as far as possible from the reigning climate of panic. Finally, at the end of this reframing and a new estimate of the cost of the research, a research agreement was drafted, giving us "access" to the premises and the data (Field, Archer, and Bowman 2019). The questions of independence, the right to withdraw, personal safety, and data security were formalized in a research agreement, in terms that reassured and satisfied us.

Before going out in the field, we took time to concretize the measures to protect data and people. In our view, the interviews in the central and interregional administrations, and even more the ethnographic approach that embodied the whole interest of the project, implied an intensive presence in the RAU as well as gathering occasionally sensitive information on the professionals exposed and the prisoners considered as dangerous; it also implied 
doing this in an institution that vibrated with even more anxiety than usual. In this context and for obvious reasons of security and professional ethics, data protection was a full-fledged task requiring original protocols: encoding the field journal, encrypting data and computer devices, use of a secure cloud storage, using hidden copies, refraining from electronic communication and so on. These protocols were a source of stress and anxiety for the researchers - nevertheless reassuring for they could say to themselves " at least we did everything we could." The protocols were also associated with heavy injunctions, especially regarding the anonymity of the institutions and actors studied.

\section{From Mistrust to Paranoia in the Prison}

Against a singularly intense backdrop of an anti-terrorism campaign that is emotive and politicized, this second section illustrates the challenges raised by any ethnographic research in prison. It also discusses three "methodological pathways": "stages," "techniques," and "positionality" (Hahonou and Martin 2019) that organize the work and the ethnographic reflection.

\section{Stages}

In each of the three prisons included in the study, the prison-based field was launched with a meeting between the research team and the professionals working in the RAU, along with other staff representatives, such as the trade union rep, the prison director, or staff responsible for the buildings. This was our occasion to introduce the team and the tasks various members would be carrying out (in-prison study field, interviews on the outside, document analysis, etc.), to explain the conditions for the study, its professional ethics and security protocol, and more generally create a climate of trust without which the ethnographic field would be doomed to failure. During this first meeting, we were able to realize the climate of extreme tension underlying the opening of the RAU, a tension we would have to adapt to. Obtaining access to the field required not only establishing a research agreement with the prison administration directors, but also negotiating at the local level and demonstrating that we clearly understood the difficulties and hesitations of the professionals in the field.

\section{First Meeting-Between Mistrust and Panic}

Quite impressed, we enter into the largest prison in Europe, located in the Paris region. The RAU is on the fourth floor of building five, but we will only visit it after an introductory meeting with about 20 professionals and 
the management team. The charismatic prison director visibly ignores us; her uncommunicative body language reveals her hostility towards our presence. "She feels trapped by the hierarchy" someone explains later, she was being forced to accept a study on high-risk units, at the very time that the RAU have just opened. We present the object of the research, all the while reassuring the professionals: "we're used to undertaking studies in prisons", "we will be discreet", "we respect the work done by the professionals", "the interviews are voluntary and anonymous", and so on. Our presentation met with an uncomfortable silence, showing that our attempts to "tame" the staff were a complete failure. Finally, a probation officer speaks up, and in an exasperated tone of voice, explains that our presence is intolerable, those who commissioned the study are completely clueless, that it is completely absurd to conduct a study on a new unit. During this uncomfortable discussion, we try to calm things down by announcing that we can always begin the study in a different prison and return six months later, when things will be a bit clearer. The professionals appreciate our gesture confirming that their opinion is important to us and seem to be reassured. And as a matter of fact, we see six months later that the conditions are suitable to conduct a field study in this prison.

The ethnographic method implies adopting the status of the "intruder" who comes into a place that has absolutely no need for a researcher to do its job. This observation is all the more true in prison which is a tight and hermetic place (Scheer 2017). The researcher's presence is extremely visible and equivocal, ${ }^{4}$ depending on the way they are seen by "others." Furthermore, the prison is a social world that is regularly presented, perceived, and undergone as polarized and conflictual. In this context, ethnographic work is often experienced as "punishing fieldwork" (Gibson-Light and Seim 2020). The researchers thus find themselves "in the crossfire" (Becker 1967), observing and interviewing both the staff and the prisoners. This particular positioning in prison was compounded by our specific field, namely detention units marked by a frank opposition between the prison officers and the prisoners, and by a climate of suspicion and constant defiance (Chantraine and Scheer 2020). The RAUs are among the most heavily secured areas in French prisons, where the prison officers must maintain control of prisoners who are reputed to be the most dangerous. As such, the RAUs are a paroxysmal incarnation of a prison underpinned by a warrior rationality and conceived as an special unit to neutralize the "enemy" (Chantraine 2009; Pires 2011). The French term for doing fieldwork: "faire du terrain" has a warlike etymology (Pulman 1988; Albera 2001); the analogy here takes on full meaning. As a "professional stranger" (Agar 1996), the ethnographer is always a suspect in the prison. 


\section{"Techniques" and "Edifying Qualms"}

The ethnographic field in the RAU, in addition to being a site of conflict in itself, also presents a "situational danger" for the researcher (Lee 1995). From the start, implicitly and sometimes quite explicitly, the researcher is suspected of not being who they claim to be: they are thought to be an agent of the French intelligence service - the General Directorate for Internal Security (DGSI), a "police inspector," or a "journalist." They are accused of having access to sensitive information and to techniques that can be of use to the "other side": certain informal means of surveillance but also to the prisoners' dissembling and workaround tactics.

\section{Fearing the Spy}

During the first days in RAU $n^{\circ} 1$, I try to introduce myself to all the actors on-site - starting with the prison officers and the prisoners - and to explain the means and goals of the study. I spend a lot of time in the corridors. I quickly notice that prison officers alike wonder what I'm doing here, in an attitude tinged with mistrust, and even hostility. Some prisoners eye me scornfully, greeting me with "here comes the DGSI"; others laugh showing their skepticism when I attempt to explain why I am here. And others immediately announce their point of view: "We know perfectly well who you are, but we won't tell you a thing". Some prison officers think that the research has been commissioned by their immediate hierarchy or the prison intelligence services in order to assess the quality of their work.

Nonetheless, over time, and because the team already has solid field experience in prison, the actors accepted the researchers' presence, allowing them to "make their way" in the RAU during the period of the study. The negotiations prior to the study and the research agreement that took so long to prepare served a purpose by providing the researchers with a relative institutional stability. Whether in the prison or during interviews with the central or interregional directorate, it was easy for us to provide full details on our security protocols to those who asked. This reinforced our "professionalism" in the eyes of our interlocutors, a professionalism which, in view of our objective, was a sine qua non for building trust. ${ }^{5}$ In the prison, the rules of the ethnographic approach were scrupulously respected: spend time, spend more time, listen and respect, be present yet discreet, discreet yet present.

The inductive approach implies "letting oneself be carried" by the field and noticing one's own surprise with all the reflexivity implied by ethnographic work (Pels 2000; Davies 2008). At the end of a day in the field, the researcher who was in the prison held a debriefing with the rest of the team. Thanks to encrypted voice notes, recorded on leaving the prison after each 
field day and then destroyed, the rest of the team was able to follow each step or progress made, but also each doubt. In this context, a strange impression of "being watched" gradually spread, to the point that it became a recurring topic of discussion. We tried to reassure ourselves: each fieldwork implies being observed in turn, and it was completely normal to feel this even stronger in the sealed atmosphere of the prison. Nevertheless, we had the impression that the climate of suspicion that reigned in the RAU pervaded the ethnographic approach from end to end. The field journals were dotted throughout with question marks: "Who do they take me for? Was the prison officer reading my field journal over my shoulder? Am I being followed? Am I being tapped? If the prison officers have a camera monitoring the room where I do the interviews, are they also able to listen in?" Bit by bit, we began to feel that we were subject to an unheard-of surveillance. While vigilance by the prison staff is regularly legitimized in the name of "our own safety," another form of surveillance, real or imagined, began to take shape. This impression of suspicion grew in pace with the volume of writing in our field journals, as the interviews became more and more rich and we began to have information that was both partial (Drake 2015) and potentially sensitive - as the researcher does not (always) control the information transmitted to them (Cefaï and Amiraux 2002).

\section{A Contagious Mistrust}

Although most of the prisoners accept the principle of the interview, they sometimes have doubts about whether they really remain confidential. Some shrug their shoulders, others explain that they are sure the room where we hold the interviews is being tapped. Today's interview with Wahid was especially strange. He gives me detailed accounts about when he was arrested, his daily life in the jail cell, his visits in the visiting room, then every now and then he suddenly stops. As if someone had walked into the room. Yet the door remains closed the whole two hours of the interview. His story is punctuated with "no, that's something I can't tell. . . well I can tell you that. . . but not here. . .". I can't help thinking that Wahid's mistrust is exaggerated, especially when he explains that there are hidden microphones in his cell, or that certain prisoners are actually intelligence agent infiltrators. Later in the day, during a meal shared with the prison officers, one of them asks me about my interview with Wahid: "he was all stressed out, wasn't he? He kept squirming in his chair. Did he tell you about the visits with his mother or not?" I reply with a vague: "the interview went well", without revealing the contents, despite the feeling of distrust that comes over me. I know that the prison officers closely follow my conversations with the prisoners, through the images transmitted by the camera in the interview room. Officially, these prison officers are allowed to monitor only the images of the interaction - primarily so they are able to protect us and 
intervene quickly in case of a problem - but in no case can they listen to the conversations. Yet were they listening in anyway? Maybe. . Here again, the surveillance expresses a twofold tension, between real and imagined surveillance on one hand, protection and control on the other - at the edge of legality.

The reflexivity relative to the anthropological approach has shown that an ethnographic presence implies being taken up in the issues at stake for identity and power (Agier 1997). Both the research agreement between the prison administration and the CNRS and the general framework imposed by the CNIL (aforementioned) provide a high level of protection for the prisoners. They oblige the ethnographer to multiply the usual efforts to ensure confidentiality and the anonymity of the persons interviewed. Each bit of identifying information is removed from the very start of the data-collecting phase and the final report must be written to make sure that no detail can identify who said what, even if certain information, deemed too personal, must be deleted (Burgess 1985; Tunnell 1998). Nonetheless, the researcher cannot be $100 \%$ sure that they have not become an inadvertent accomplice of the surveillance apparatus. This persistent doubt is the source of the unsettling "edifying qualms" that dog the researcher, but it is also instructive for the research as it illustrates how the fight against terrorism forges a persistent feeling among the prisoners - and the researchers as well - that at any time, the institution may be inclined to eschew the obligation to respect the right to confidential conversations, or even the law itself, in the search for information it deems to be especially important. The omnipresence of the prison intelligence mission (Scheer and Chantraine Forthcoming) merely feeds this impression. Furthermore, in the journal extract above, Wahid is speaking face-to-face with a researcher but also addressing a potential and virtual third party (the "prison authorities," or even the "judge" or "public opinion") which may possibly have access to the contents of the interview. Paradoxically, this ambiguity is the source of quite interesting information during the conversation, with the interview becoming a virtual tribune of sorts during which Wahid had the opportunity to criticize the way he was being treated and to develop an elaborate criticism of the operation of the unit in which he was incarcerated, which did not allow him to prove he was not radicalized. Thus, while the negotiations between the institutional actors and the prisoners are asymmetrical as they are marked by the prison's structural domination relations, the researcher nevertheless manages to negotiate a framework for exchange and interaction with the prisoners in which the prisoners may see their own interest in cooperating. 


\section{"Positionality," Exteriority, Critics}

Our presence in the most heavily secured prison units in France, our daily interviews with prisoners who were the most heavily guarded by the national security forces, and our contact with the staff responsible for them modified the local issues at stake and the power relationships between the prisoners and the professionals, between the "base" professionals and their hierarchy. The actors observed thus had a new channel for communication and visibility: the researcher during the interviews and many informal discussions. The administrative management, members of the hierarchy, or people responsible for monitoring the actors we observed were aware of this new situation. In this context, it was no surprise that we were under surveillance, as agents who disturbed the precarious equilibriums and power relationships, but also as people who held information that was potentially interesting both for the professionals in charge of assessment in the RAU and the intelligence agents. The art of ethnography occasionally consists in eluding the question, for example, satisfying the curiosity of a professional wanting to know how an interview went, all the while maintaining the honesty needed to continue the fieldwork smoothly (Crewe and Ievins 2015).

\section{From "Complete Refusal" to Active Participation in the Research}

A few weeks after the start of the field work in RAU n ${ }^{\circ} 3$, Ms. Carole, the prison director, mentions the prisoner Omar whom I haven't yet met for an interview. She explains the prisoner's stance of "total refusal": he accepts no interviews and refuses all forms of cooperation with the administration. Despite a lot of insistence and several attempts, Omar has always refused. She warns me that he will turn down all my requests and adds, with a laugh: "If he accepts to talk to you, then my name sure isn't Ms. Carole!'. The next day I propose an interview to Omar. Before I even get a chance to explain the research, he accepts. "Just let me finish my cigarette, then we're on." After a three-hour interview in a room relatively sheltered from view, Omar is taken back to his cell. The director calls me, an amused tone in her voice: "How did you manage that? The deputy told me that Omar had accepted an interview with you. Incredible! I thought you two would never leave that room!" After inviting me into her office and closing the door, she questions me about what Omar had to say. I limit myself to saying that the interview was interesting, without giving more details.

Here, the prison officers' reaction reflects both the effectiveness of the confidential exchanges (they are frustrated at know nothing about the contents of the in-depth interview with the researcher) and the inherent limits of rendering them anonymous, since the prison officers' management of movements inside the unit logically implies knowing who participates in the interviews and who does not. As such, Omar, just like Wahid above, understood that the 
context of the research interaction would enable him to not be the object of criminological curiosity about his radicalization path, but rather the subject of a unique carceral experience that he could report on. In terms of positionality, the researcher's art is to succeed, despite persisting ambiguities, in creating a climate of confidence that places the researcher in a position of exteriority toward the institution, thus enabling the prisoner to feel he can cooperate with the former.

Despite this cooperation and researchers' success in demonstrating this institutional exteriority, the hyper-surveillance the prisoners are subject to thus began to color the researchers' impressions as well, as they started wondering to what extent they were "inventing scenarios in their heads" or becoming "paranoiacs." The prisoners, on their side, explained that they were constantly observed and listened to in their cells or watched by stool pigeons placed in the visiting rooms. Although some of these suspicions were well founded-phone conversations, for example, were tapped and transcribed and certain plain-clothed officers blended in with families waiting for the visiting room to open - this mistrust is also often imagined: to our knowledge no microphones were placed in the cells. However, several incidents reinforce this notion about undercover tapping: people in suits accompanying workers doing invisible work in the exercise yard ("are they planting forbidden mics?" they asked), the sound of a device clicking on in the evening when fewer prison officers were on duty, black cars with tinted windows authorized to enter the prison grounds and park near the building housing the RAU, and so on. Furthermore, the prisoners were not the only ones to feel this way. Even though we are not able to confirm their remarks, some psychologists told us that their desk drawers had been broken that their draft interview notes had been stolen. Educators explained that they were aware of in-house memos mentioning their "excessive closeness" to the prisoners. A prison intelligence agent explained that he did not divulge his religious faith to avoid raising suspicion among his colleagues. Gradually, these anecdotes coupled with the general climate of defiance, suspicion, and surveillance, forged in the researchers a "panoptic personality" (Lyons 2004), in other words, the feeling that all their actions could be observed at all times. In the context of this research, however, there was something particular in the way it extended beyond the spatial area of the prison, thus reinforcing its encompassing and anxiety-provoking nature.

\section{Surveillance Outside Prison Walls}

Certain signs gradually led us to suspect, then actually notice that the monitoring we were subject to did not end at the prison gate. For example, we learned 
from someone well acquainted with the intelligence service operations that "it would be surprising if you were not being closely followed" - even though, at this stage, we had no idea what that meant in concrete terms. Once again, we can note the extent to which forms of control, negotiation, and surveillance do not occur in a uniform manner, but assume different forms depending on the type of actors involved. In this case, the action of the prison intelligence agents ${ }^{6}$ gradually became pervasive and problematic. We even decided to reformulate our ethnographic observations along these lines, to describe how the intelligence services are an essential feature of several aspects of daily life, work, and research in the RAU (Scheer and Chantraine Forthcoming). Intelligence works with discreet means and secrecy. As time went by, we decoded more of these often-invisible aspects of the work. Things that went unsaid at the time were deciphered afterward: a professional encountered in his job as an Islamologist, we later find out, is part of an intelligence service; a prison officer who eluded questions about his career future, we learn several months after the study, ended up joining a prison intelligence unit; and so on. Moreover, the presence of nonidentified persons not listed in meeting reports confirmed the permanence and the pervasion of this hidden intelligence facet, generalized in the field that we observed and of which we were surely targets.

During a discussion in the prison with a prison intelligence agent, the police officers in charge of tailing involuntarily "betrayed themselves" by recognizing us - even though we were meeting for the first time. These elements that confirmed that we were being followed bolstered a feeling we already had but which was still just a vague impression.

\section{An Uneasiness that Says a Lot}

After 12 weeks of observation in RAU n 2 , a senior prison officer who regularly comes to "reinforce" the guardian team takes advantage of a moment alone with me in the hallway to admit that he's a prison intelligence agent. He wants to explain his point of view, but "in all discretion". We make an appointment for an interview the next day in the late afternoon. The next day, I walk towards the office he indicated to me. Absolutely nothing is written on the door, nothing to tell me if I'm in the right place. I knock on the door. He opens it, looking right and left before letting me in. Before explaining his work and point of view about monitoring the prisoners, the agent wants to make sure I'm not in contact with any journalists. Reassured and pleased to have someone to talk to, he explains in detail his daily surveillance work, the priorities for surveillance, identifying threats and his relations with the national security forces, domestic intelligence agencies and the police. But the interview is suddenly interrupted. There's a knock at the door. The agent lets two people into the office, a man and woman in plain clothes. Before he sees me, the man says, "We've come to see you about Souleiman". To my great surprise, the woman greets me warmly, 
with a big smile. "Oh, good evening, how are things going?" Her colleague turns towards me and after a moment, recovers his astonishment and remonstrates her, a bit embarrassed: "Hmm, you're not supposed to know who he is. . ."We exchange a few embarrassed smiles. They speak for a few minutes with the prison intelligence agent, being careful not to mention any names. After they leave, the prison intelligence agent explains that they are police officers whom he meets regularly, "here or at a bar" to exchange information on the prisoners or on "radicalized" prisoners. He adds: "And since you probably have a lot of information, it's not surprising that they're following you closely. They are also in charge of tailing."

Before describing some other concrete modes of surveillance, we want to detail the "encompassing" or even "encompassed" nature of the ethnographic immersion undertaken in the prison. In fact, conducting a study on and in a special unit that was still in the experimental phase, and one that is quite regularly in the sights of the administration or politicians and ceaselessly presented as being at the center of the fight against terrorism and foiling threats to national security meant that we ourselves were taken up with this climate of emulation and definition of national priorities. In other words, the researchers, sometimes despite themselves, ended up imbibing the political, social, and private atmosphere of the fight against terrorism.

Furthermore, it was a question of "taking full advantage" of access to the field, in other words, to pass as much time there as possible. The team was keenly aware that the methodological structure set up was at constant risk of being challenged or renegotiated, and that an incident inside or outside the prison could put a sudden end to the field. What was more, the prevailing climate in cities and its implications on our daily research routines - controls by soldiers deployed in the streets, alerts for parcel bombs in public transport on the way to the prison, palpable fear of new attacks, stigmatization of certain neighborhoods and places frequented by the researchers - reinforced the impression that the ethnographic immersion was encompassed in a broader social and subjective experience.

The ethnographic commitment incited the team to continue their pursuit of this rare and potentially ephemeral field, despite the surveillance. Just like the RAUs were part of an environment that spread beyond the prison and raised more general questions about managing threats to national security, the surveillance we were subject to continued outside the prison walls. During our discussions on the outside, at the DAP, but also during professional seminars or with sources close to government bodies, some participants seemed to have a quite detailed knowledge of the very field that we were working in at the prison. Furthermore, we had the impression-occasionally confirmed —of 
being followed at the end of a day's observation in the prison and as well as at other times. We realized that the warning given at our first meeting was definitely not a metaphor.

Being under surveillance thus took on a whole different dimension for researchers. Usually, those who do fieldwork in prisons know this immediate feeling of "liberation" when, at the end of a day spent along prison corridors, they pass the prison turnstile toward the exit and "open air," when those who smoke light up a cigarette to enhance this feeling of immediate relaxation. But in the case at hand, surveillance became constant and porous.

\section{Researchers Being Bugged?}

Since we have decided to restrict as far as possible our distance communications, by email or phone, we have decided to get together in the same city in France for a team meeting. Several electronic incidents already caught our attention a loading bar that appears on the telephone screen, emails that take some time to be transmitted, a telephone that emits strange sounds for no apparent reason, deteriorated call quality. We find ourselves on the station platform: "I wanted to warn you I'd be late, but my phone went dead. Impossible to turn it back on, even though my battery was charged." We both look at our phones: and in fact, they are both cut off, showing the same black screen. Neither of us manage to turn our phones back on until several hours later.

In addition to the telephone dysfunctions, like being unable to complete certain calls, texts from other team members (and solely other team members) showing a long delay between sending and receiving, or even unknown numbers displayed when we made calls, there was the impression of being followed physically and numerically. One person might follow the same itinerary as ours, through streets with few pedestrians, on the way from the prison to the station; another might wait all alone on the commuter train platform until we entered the train before doing the same. Another example: during a steering committee meeting, an unidentified person - we learned later that he was part of the prison intelligence services - took copious notes and then suddenly left the meeting. And lastly, a researcher's laptop was stolen in a restaurant, the same day as an attempted robbery occurred at the home of this same researcher. It is important here to stress the fact that our aim is not to provide material proof that all these elements are interconnected, but rather to describe the way the "panoptic personality," as a subjective experience, led us constantly to formulate hypotheses on the possible links between the various events. On occasion, this surveillance became visible and explicit, such as an unexpected encounter in the restroom of a bar, along with a "Greetings. DGSI!" 


\section{A "Privy" Conversation}

After a day of fieldwork, we decide to do our debriefing on the terrace of a cafe, while waiting for the train one of us will be taking. We discuss the day's events, compare our observations and share our impressions. We are careful to speak softly and not mention any names. But we don't immediately notice that three men have sat down at the table just behind us. Several minutes later one of us goes to the restroom. The room is deserted, yet someone walks up to the urinal just next to the one I'm using, breaking all the rules of male courtesy in such situations, all the more so when he speaks to me, using the familiar tu: " $\mathrm{Hi}$, how's it going? Nice beard! So, what do you do in life? Are you from Paris?" I reply that I'm a researcher in sociology and that I'm in Paris for work, without giving more details, and then move to the sink to wash my hands. He follows closely. "In any case, in your job, it must help to have a beard like that. Oh, and let me introduce myself: Greetings. DGSI." After a moment of stupor, I go back upstairs to my colleague. I describe my encounter and we realize it was one of the men seated behind us. But they have already left.

The fact that we were being followed and watched, whether voluntarily discreet or willfully rude, fit into a dialectical relation between protection and surveillance. On several occasions, we were almost on the verge of ending the research; we thought about warning our project commissioners, but maybe they were already aware; we reviewed our security protocols and better ways to protect the information we had collected.

This surveillance both engendered and revealed conflicts of loyalty. To begin with, it installed a relationship of mistrust in an ethnographic field that usually requires efforts to be accepted, "to makes one's way" (Scheer 2017), and create a climate of trust with those being studied. During this research, we had to cope with our own suspicion and mistrust of our project commissioners, the people we were studying, and the government services. This mistrust was coupled with the fear of betraying the prisoners, professionals, authorities, or national surveillance services, perhaps despite all our efforts. Indeed, the fact that we were collecting sensitive information on all these sides meant that we could be in trouble if one or another information were to be revealed. We had to cope with this fear of being suspected of betrayal. ${ }^{7}$ In particular, doing a study under surveillance, in a closely monitored field, and especially one about surveillance professionals and their targets raised major questions regarding relationships with power. As such, the surveillance we were subject to shed light both on the object studied and on the context for creating the data needed for the analysis. As researchers, we had access to a range of "territories": surveillance sites, prison cells, intelligence service offices, the prisoners" collective activities, as well as to a range of "shared knowledge": surveillance tools and protocols, the prisoners' dissembling 
strategies, the grid for detecting radicalization, subversive discourses. These accesses enabled us to map relationships of power as a function of the places and actors on hand (Wood 2006), thus revealing things like the warlike relationship between the prison officers and the prisoners, conflicts of professional jurisdiction, asymmetrical roles with respect to administrative decision making, and so on. In addition, the researcher's unusual position of speaking with all parties involved reflected a classical image in espionage (Borneman and Masco 2015): a liberty that allows one to suspect complicity with power and the idea of someone who is always playing a double game.

Quite evidently, these observations and this feeling of being the target of close surveillance impacted the research work through questions that were both simple and haunting: What to accept and what to refuse? How could we "live with it" and why should we? This question took on full meaning when a car followed us one evening as we left one of our fields.

\section{Scrutinized, But by Whom?}

It is late by the time I leave the field, in the prison, around $8 \mathrm{pm}$. In a hurry to reach the commuter station, I take some small roads with little traffic. A car is driving slowly just a few meters behind me. It stops when it reaches me. The passenger lowers the window. I can see three people inside. The driver is wearing a cap and jeans, and the passenger is in a djellaba. Their sinister looking faces aren't very reassuring. "Can I help you?", I venture awkwardly, all the while moving closer to the car to be able to block the door if someone tries to get out. The car suddenly takes off only to stop several meters on. I can't turn around; that would be a sure sign that I was running off and they could easily catch up. So, I keep on walking, not feeling too sure of the situation. I come up to where the car is stopped. The windows are rolled back up. I try to act nonchalant and nod at them all the while continuing on my way. The car drives along at my pace. I try not to walk faster nor slow down. The hundred meters to the next intersection feel like kilometers. I reach the crossroads towards the station; there are people around. The car zooms off, squealing its tires. I try to remember the license plate number but immediately forget. I decide the stop for a few minutes in the station which is fairly busy. Going up to an empty train platform on the other side of the tracks seems like an ordeal right now. I get out my Dictaphone, my voice still trembling, to record a memo about what has just happened, and I jot down a few words in my field journal: "Who were these people? The French intelligence service, or an intimidation ordered by one or another prisoner who has doubts about my identity?"

Those looks exchanged, and the doubt gives way to fear: is this an indiscreet tailing by the French intelligence services or an intimidation ordered by one or another prisoner in the RAU? To what extent are we being followed? And by whom? Have we brought this on ourselves? Did we go too far? 


\section{Conclusion: Surveillance and Prison Change}

This account about the conditions of an ethnographic research on the RAU in French prisons is a glaring illustration of the ambiguities of a commissioned research: the researchers are invited into the institution by the prison administration's "research office." Yet once inside, they are viewed with deep suspicion by this very administration and subject to quite intense forms of surveillance, such as tapped phones and being tailed after leaving the site. These issues were especially pronounced in this project because of the specifics of the political context, but they also highlight issues ubiquitous to prison ethnography: gaining access requires researchers to align with authorities, but research findings are always potentially threatening or damaging to those same authorities.

Viewing the situation through the perspective of grounded theory and the inductive approach implies, in various degrees, transforming the object of study in the light of discoveries emerging from the field or methodological adaptations during the course of the study (Boumaza and Campana 2007). The feeling of being watched also enlightened our field. As the observation work progressed, surveillance gradually became the subject of our study, an object of research in itself. While these transformation dynamics can be broadly problematized at levels above the field, it is only during the fieldwork itself that they emerge as tangible objects to be investigated. In the case of the RAU, we were aware that ethnographic immersion would be needed, for example, to reconstruct the concrete activity of each professional and their relations with others or to grasp the impact of an ultra-security architecture on the relations of defiance between the prison officers and the prisoners. On the other hand, only once we were in the field did we realize we had to make room for an analysis of a new form of surveillance that does not completely overlap with traditional carceral logics, one that is undertaken by actors who are almost invisible, yet henceforth incontrovertible: the intelligence agents.

On this subject, the final step of the research — writing then delivering the report - must be mentioned here. At the end of the ethnographic field and the data collection phase, the researchers returned to their offices, individually or collectively, to analyze the material and prepare the final research report. During this period, we maintained our data security protocols by limiting our communications or keeping our telephones far outside our meetings. As we wrote, even draft versions, we doubled our efforts to keep everything anonymous: protecting individuals always held priority, even if it affected the finesse of some analytical descriptions. ${ }^{8}$ Thus, occasionally, with regret, we had to delete certain remarks or even abandon complete analysis paths, 
knowing they might lead to people being recognized. We also decided that the official report would not mention the surveillance we ourselves were subject to, but to keep this reflexive dimension to a primarily scientific audience in the context of this article.

When we had finished writing the report, we visited the offices of the DAP for a meeting to deliver the final research report. We were met by members of the DAP "research unit" who ushered us into a meeting room. Several other prison managers and directors joined us: representatives of the MLRV, a prison director, and other people we did not recognize. Surprised that the composition of this meeting did not correspond to the steering committee initially negotiated, we asked if we could go around the table so the attendees could introduce themselves. Three persons presented themselves by giving an office number (we understood that they were part of the national prison intelligence service) without stating their names. The meeting concerned the contents of the report sent electronically a few days earlier. Each participant gave their comments on the text; some asked for slight changes. Quickly, and not without some tension, we were asked to remove the whole chapter on prison intelligence, for reasons of national security. After discussions, we accepted to remove about 15 pages of this official report. We immediately began to think of other ways we could respect the injunction weighing on us, finding a way to write about prison intelligence without too much detail on the highly sensitive professional's practices, yet without diluting our sociological analysis - what we have done (Scheer and Chantraine Forthcoming).

This article is obviously too short to enable us to address all the problems relating to monitoring and surveillance of activities that we encountered in the context of this study. Questions such as self-monitoring and self-censorship, or that of fear, for example, could have been discussed more extensively. Thus, our only option is to settle for a conclusion as a form of opening and then re-situate the reflection in the evolution of objects of research in the sociology of prison.

Indeed it is important to stress that fact that this is not a question of merely renewing a careful ethnography of surveillance and observation modes toward the prisoners to ponder the unique economy of the exercise of carceral power (Chantraine, Scheer, and Milhaud 2012; Chantraine and Sallée 2015). It is also a question of realizing that surveillance of the researchers both in the prison and outside is an incontrovertible facet of this renewed economy. In other words, surveillance of research beyond prison walls is one element among others in the way the RAU operates. More generally, the surveillance of researchers in the prison, from the prison, and outside the prison represents a more generalized reconfiguration of the relations that the prison maintains with its environment in 
relation to managing individuals and populations (Wacquant 2002; Veaudor 2020). Studies have described the integration of the prison "surveillance culture" in reintegration practices and services (Prior 2020). However, the extension we are writing about here is something else. In this case, surveillance is extended, both in terms of targets - people charged with a crime are no longer the only suspects - and in terms of geography, throughout and beyond the prison. Although the analysis of these relations has been dealt with extensively from the angle of urban questions (to cite just one example among too many reflections on this subject, see Weegels, Jefferson, and Martin 2020), much less has been written from the angle of surveillance and intelligence practices. This is certainly an essential object that must be studied for it is the symptom of a significant institutional transformation that reflects the way the prison has drawn closer to the Ministry of the Interior (Observatoire International des Prisons 2019) and a form of policization of prison services (Quinquis 2016). The conditions for producing scientific knowledge - in this case, the decarceralization of surveillancethus enlightens us not only regarding how a study is conducted or the ethnographic strategies deployed (Bizeul 1998), but also regarding the way institutions are transformed, in this case, more broadly on the frontiers of surveillance. We can observe a form of governance through suspicion, in which the use of (shared?) secrecy and covert surveillance predominate.

More essentially, the relation between the research object and the researchers - the sub-field (Abélès 2004) — enlightens an essential extension of the analysis. The conditions for production provide information on the object studied, in this case on its frontiers. The prison is gradually losing its spatial dimension; Foucault (2004) would perhaps speak of a "liberation of carceral functions." Indeed, the prison institution becomes a tool for general surveillance making it possible no longer to supervise individuals during their period of incarceration, but also to implement monitoring within and outside prison walls, to establish "profiles" and identify networks. Our usual context, "sociology of prison," is gradually becoming a hybrid along with another field of study, that of "surveillance studies" (Ball, Haggerty, and Lyon 2012; McNeill 2019). The reflexive work re-integrates the surveillance we have been subjected to in the thought process, for a more objective view of how the prison is changing, and more generally to observe, from the bottom-up, certain modalities for transformations of the State itself.

\section{Declaration of Conflicting Interests}

The author(s) declared no potential conflicts of interest with respect to the research, authorship, and/or publication of this article. 


\section{Funding}

The author(s) disclosed receipt of the following financial support for the research, authorship, and/or publication of this article: This work was supported by the French prison administration (Direction de l'administration pénitentiaire), within the framework of a research convention between the administration and the National Centre for Scientific Research (CNRS, France).

\section{ORCID iD}

Gilles Chantraine (iD) https://orcid.org/0000-0002-4760-8879

\section{Notes}

1. Although "radicalization" is not clearly defined in the texts establishing these units, it is worth noting that only prisoners (identified as or suspected of being) radicalized in relation to Islam are sent to these RAU. Indeed, at present, no other form of political violence is assessed in the RAU and the professionals working there are specialized in handling and evaluating Salafi jihadism.

2. For example, following a prison officer's observation of the prisoner's behavior, or after an informer reports them for being radicalized or else on the basis of the prisoner's relations with other prisoners already identified as radicalized.

3. Since then the office has been replaced by a "research and innovation laboratory."

4. On the question of (in)visibility as an ethnographic research method, see Chapter 6.2 "Becoming invisible" in Berg and Lune (2012).

5. This is not always the case. In other situations and other research objects, the image of a "student learning the trade," for example, may be preferable.

6. In France, prison intelligence has developed massively since 2016, sparking major institutional changes: integration of intelligence personnel at a high level of the prison hierarchy, spread of a culture of secrecy in the prison, integration of investigation, and threat detection logics in the daily work of the prison staff.

7. For another account of the fear of doubt and fear of being considered a traitor, in a completely different context, see Thorne (1983).

8. On ethics in qualitative research, see Traianou (2014).

\section{References}

Abélès, M. 2004. "Le Terrain Et Le Sous-Terrain." In De L'ethnographie À L'anthropolgie Réflexive. Nouveaux Terrains, Nouvelles Pratiques, Nouveaux Enjeux, edited by C. Ghasarian, 35-44. Paris: Armand Colin.

Agar, M. 1996. The Professional Stranger: An Informal Introduction to Ethnography. 2nd ed. San Diego, CA: Academic Press.

Agier, M. (ed.). 1997. Anthropologues en dangers: l'engagement sur le terrain. Paris: Jean-Michel Place.

Albera, D. 2001. “Terrains minés.” Ethnologie Francaise 31 (1): 5-13. doi: 10.3917/ ethn.011.0005 
Ball, K., K. Haggerty, and D. Lyon. 2012. Routledge Handbook of Surveillance Studies. Abingdon: Routledge.

Becker, H. 1967. "Whose Side Are We On ?" Social Problems 14 (3): 239-257. Doi: $10.2307 / 799147$

Berg, B. L., and H. Lune. 2012. Qualitative Research Methods for the Social Sciences. 8th ed. Boston: Pearson.

Bizeul, D. 1998. “Le Récit Des Conditions D’enquête: Exploiter L’information En Connaissance De Cause." Revue Française de Sociologie 39 (4): 751-787. doi: $10.2307 / 3323009$.

Borneman, J., and J. Masco. 2015. "Anthropology and the Security State: Public Anthropology." American Anthropologist 117 (4): 781-785. doi: 10.1111/ aman.12371.

Boumaza, M., and A. Campana. 2007. "Enquêter en Milieu « difficile »: Introduction." Revue Française De Science Politique 57 (1): 5. doi: 10.3917/rfsp.571.0005.

Bosworth, M. 1999. Engendering Resistance: Agency and Power in Women's Prisons. Aldershot: Dartmouth.

Burgess, R. 1985. "The Whole Truth? Some Ethical Problems of Research in a Comprehensive School." In Strategies of Educational Research: Qualitative Methods, edited by R. Burgess, 141-162. Lewes: Falmer Press.

Cefaï, D., and V. Amiraux. 2002. "Les Risques Du Métier. Engagements Problématiques En Sciences Sociales. Partie 1." Cultures \& Conflits 47 (3): 1548. doi: 10.4000/conflits.829.

Chantraine, G. 2004. Par-Delà Les Murs. Expériences et Trajectoires en Maison D'arrêt. Paris: PUF/Le Monde.

Chantraine, G. 2009. "Les Savoirs Des Prisons. Rationalité Punitive et Savoirs Critiques." Tracés 9:99-110. doi:10.4000/traces.4381

Chantraine, G., and N. Sallée. 2015. "Ethnography of Writings in Prison: Professional Power Struggles Surrounding a Digital Notebook in a Prison for Minors." In The Palgrave Handbook of Prison Ethnography, edited by D. Drake, R. Earle, and J. Sloan, 99-123. London: Palgrave Macmillan.

Chantraine, G., D. Scheer, and O. Milhaud. 2012. "Space and Surveillance In a Prison for Minors." Politix 25 (97): 125-148. doi :10.3917/pox.097.0125

Chantraine, G., and D. Scheer. 2020. "Performing the Enemy? No-Risk Logic and The Assessment of Prisoners in "Radicalization Assessment Units" in French." Punishment \& Society. https://journals.sagepub.com/doi/10.1177/1462474520952147.

Clemmer, D. 1958. The Prison Community. New-York, NY: Rinehart.

Crewe, B. 2009. The Prisoner Society: Power, Adaptation and Social Life in a English Prison. Oxford; New-York: Oxford University Press.

Crewe, B., and A. Ievins. 2015. "Closeness, Distance and Honesty in Prison Ethnography." In The Palgrave Handbook of Prison Ethnography, edited by D. H. Drake, R. Earle, and J. Sloan, 124-142. London: Palgrave Macmillan. doi: 10.1057/9781137403889_7.

Davies, C. A. 2008. Reflexive Ethnography: A Guide to Researching Selves and Others (The ASA Research Methods). 2nd ed. New York, NY: Routledge. 
Drake, D. H. 2015. "Finding Secrets and Secret Findings: Confronting the Limits of the Ethnographer's Gaze." In The Palgrave Handbook of Prison Ethnography, edited by D. H. Drake, R. Earle, and J. Sloan, 252-270. London: Palgrave Macmillan. doi: 10.1057/9781137403889_14.

Fassin, É. 2015. L'ombre du Monde Une Anthropologie de la Condition Carcérale. Paris: Éditions du Seuil.

Field, C., V. Archer, and J. Bowman. 2019. "Twenty Years in Prison: Reflections on Conducting Research in Correctional Environments." The Prison Journal 99 (2): 135-149. doi:10.1177/0032885519825489.

Foucault, M. 2004. "Prisons : La Chute Des Murs ? Michel Foucault, Conférence À l'Université De Montréal, 1976 (Extraits)." Vacarme 29 (4): 142-145. doi:10.3917/vaca.029.0142.

Gibson-Light, M., and J. Seim. 2020. "Punishing Fieldwork: Penal Domination and Prison Ethnography." Journal of Contemporary Ethnography 49 (5): 666-690. doi:10.1177/0891241620932982.

Goffman, E. 1990. Asylums: Essays on the Social Situation of Mental Patients and Other Inmates. New York, NY: Anchor Books.

Hahonou, E. K., and T. M. Martin. 2019. "Immersion in the Bureaucratic Field: Methodological Pathways." Critique of Anthropology 39 (2): 122-138. doi:10. 1177/0308275X19842921

Hamilton, C. 2019. Contagion, Counter-Terrorism and Criminology: Justice in the Shadow of Terror. London: Palgrave MacMillan.

Lee, R. 1995. Dangerous Fieldwork. Thousand Oaks, CA: Sage Publications.

Liebling, A. 2001. "Whose Side are We on? Theory, Practice and Allegiances in Prisons Research." The British Journal of Criminology 41 (3): 472-484. doi: 10.1093/bjc/41.3.472

Liebling, A., and H. Arnold, 2004. Prisons and Their Moral Performance. A Study of Values, Quality, and Prison Life. Oxford; New-York: Oxford University Press.

Lyons, J. D. 2004. “Au Seuil du Panoptisme Général.” Dix-Septième Siècle 2 (223): 277-287. doi:10.3917/dss.042.0277.

Martin, T. M. 2019. "The Ethnographer As Accomplice-Edifying Qualms Of Bureaucratic Fieldwork in Kafka's Penal Colony." Critique of Anthropology 39 (2): 139-154. doi:10.1177/0308275X19842916

McNeill, F. 2019. "Mass Supervision, Misrecognition and the 'Malopticon'." Punishment \& Society 21 (2): 207-230. doi: 10.1177/1462474518755137.

Observatoire International des Prisons. 2019. “L'administration Pénitentiaire Dérive Vers l'Intérieur." oip.org. https://oip.org/analyse/4608/

Pels, D. 2000. "Reflexivity: One Step Up." Theory, Culture \& Society 17 (3): 1-25. doi:10.1177/02632760022051194.

Pires, A. 2011. "La Rationalité Pénale Moderne, la Société Du Risque et la Judiciarisation de L'opinion Publique.” Sociologie et Sociétés 33 (1): 179-204. doi: 10.7202/001562ar

Prior, F. B. 2020. "Security Culture: Surveillance and Responsibilization in a Prisoner Reentry Organization." Journal of Contemporary Ethnography 49 (3): 390-413. doi:10.1177/0891241620908651. 
Pulman, B. 1988. "Pour Une Histoire de la Notion de Terrain." Gradhiva 5 (1): 2130.www.persee.fr/doc/gradh_0764-8928_1988_num_5_1_1135

Quinquis, M. 2016. "Le Plan «Urvoas »: Un Pas de Plus Dans la Transformation Policière de L'administration Pénitentiaire. Droit Pénitentiaire.” La Revue Des Droits de L'homme. Revue du Centre de Recherches et D'études Sur Les Droits Fondamentaux. doi: 10.4000/revdh.2904.

Scheer, D. 2017. “Objets, Espaces et Corps Du Chercheur. Éléments de Réflexivité Autour D'une Recherche Sur L'architecture Carcérale." Criminocorpus. https:// journals.openedition.org/criminocorpus/3533?lang=en

Scheer, D., and G. Chantraine. Forthcoming. "Intelligence and Radicalization in French Prisons: Sociological Analysis Bottom up" Security Dialogue.

Sykes, G. 1958. The Society of Captives. A Study of a Maximum Security Prison. Princeton: Princeton University Press.

Thorne, B. 1983. "Political Activist as Participant Observer : Conflicts of Commitment in a Study of the Draft Resistance Movement in the 1960s." In Contemporary Field Research, edited by R. Emerson, 216-234. Boston, MA: Brown.

Traianou, A. 2014. "The Centrality of Ethics in Qualitative Research." In The Oxford Handbook of Qualitative Research, edited by P. Leavy, 61-78. Oxford: Oxford University Press. doi: 10.1093/oxfordhb/9780199811755.013.028.

Tunnell, K. 1998. "Interviewing the Incarcerated: Personal Notes on Ethical and Methodological Issues." In Inside Stories: Qualitative Research Reflections, edited by de Marrais K., 127-137. Mahwah, NJ: Lawrence Erlbaum Associates.

Veaudor, M. 2020. "Les « frontières » de l'ordre Carcéral. Affectation, Négociation Des Identités et Surveillance En Maison d'arrêt." PhD diss., Université VersaillesSaint-Quentin-en-Yvelines.

Wacquant, L. 2002. "The Curious Eclipse of Prison Ethnography in the Age of Mass Incarceration.” Ethnography3 (4): 371-397. doi: 10.1177/1466138102003004012 Weegels, J., A. M. Jefferson, and T. M. Martin. 2020. "Introduction: Confinement Beyond Site: Connecting Urban and Prison Ethnographies." The Cambridge Journal of Anthropology 38 (1): 1-14. doi: 10.3167/cja.2020.380102.

Wood, E. J. 2006. "The Ethical Challenges of Field Research in Conflict Zones." Qualitative Sociology 29 (3): 373-386. doi: 10.1007/s11133-006-9027-8.

\section{Author Biography}

Gilles Chantraine is a sociologist at the Centre lillois de recherches sociologiques et économiques - CNRS / Université de Lille. At the crossroads of a sociology of institutions, professions, and individual prison experiences, his work is devoted to the analysis of contemporary transformations in prisons. He is the author of Par-dela les murs (2004, PUF/Le Monde), and Bastille Nation, French Penal Politics and the Punitive Turn (2013, Red Quill Books). With Tomas Martin, he recently directed Prison Breaks, Toward a Sociology of Escape (2018, Palgrave). His current research focuses on prison management of violent extremisms.

David Scheer is a criminologist, researcher in sociology at the Centre lillois de recherches sociologiques et économiques — CNRS / Université de Lille. His work 
focuses on juvenile prisons, prison architecture, and the handling of violent extremisms in prisons. He recently published La prison. Réalités et paradoxes with Camille Lancelevée (2019, Presses universitaires Blaise Pascal) and, with Olivier Mihaud, coordinated the special issue Prison through architectural space (Champ pénal/Penal field, $\left.n^{\circ} 20,2020\right)$. He is currently developing a research program on the intelligence services' response to violent extremisms. 